\title{
AZ ÉSZAK-ALFÖLDI RÉGIÓBAN MÜKÖDÖ FITNESZSZOLGÁLTATÓK KÍNÁLATÁNAK ELEMZÉSE
}

\author{
Lenténé Puskás Andrea - Hidvégi Péter - Pucsok József Márton - \\ Czeglédi Hanna Orsolya - Bíró Melinda
}

\section{Összefoglalás}

A rekreáció, a turizmus terïletén az egészség egyre inkább a fókuszba kerül, melyet az egészséges életmód koncepcioját elötérbe helyezó fogyasztók egyrészt igényelnek, emellett a sportszolgáltatások. keresletét is növelik. Jelen kutatást az. Észak-alföldi régiói fitnesz szolgáltatói $(n=24)$ körében végeztuilk. A vizsgálat során kiváncsiak voltunk arra, bogy hogyan alakulnak az általunk vizsgált régiós fitneszszolgáltatók kinálati elemei és ezek a kinálati elemek összhangban vannak-e a keresleti trendekkel. A kutatási kérdés megválaszolásához kérdöives viæsgálatot végeztünk a szolgáltatók körében. Az adatokat Excel szoftver segitségével dolgoztuk. fel. Az eredmények értékelésekor sqámitottunk átlagot és szórást, melyeket grafikusan is ábrázoltunk.

A kapott eredmények ąt mutatták, hogy a fitneszszolgáltatók az alap és kiegészitó sqolgáltatásaikban minöségi és mennyiségi fejlesztéseket is végrehajtanak, amelyek összhangba vannak a trendekkel. A vizsgálat eredményei azt igazolták, hogy modern kondicionálótermi gépeket használnak a termekben, többféle csoportos óra megtartására alkalmas légkondicionált termeket bižtositanak a komfortosabb edzéskörnyezet megteremtése érdekében, emellett kinálnak közérzetjavitó és kiegészitö wellness szolgáltatásokat, valamint a vendégek által a szolgáltató elérhetöségét javitják a parkolóbelyek biztositásával.

Kulcsszavak: fitnesqszolgáltatás, óratipus, trend

JEL:Z2

\section{ANALYSIS OF THE OFFER OF FITNESS SERVICE PROVIDERS IN NORTH GREAT PLAIN REGION}

\begin{abstract}
Absrtact
With healthy lifestyle getting more widespread, demand for sports services is growing among health-conscious consumers as well. The present study was conducted among fitness service providers $(n=24)$ in North Plain Region. During our research we sought to find out how these service providers develop their supply elements and are these elements in line with the demand trends? Semi-structured interviews were analyzed by content analysis, which were partially processed using Excel software. Mean and standard deviation were calculated when evaluating the results.

The results show that the fitness service providers strive for both extensive and intensive development in their basic and ancillary services, which results in a fairly large number of fitness equipment, air-conditioned rooms suitable for group trainings, parking lots and wellness services that are tailored to consumer fitness trends.
\end{abstract}

Keywords: Fitness services, class or training types, trends

JEL:Z2 


\section{Bevezetés}

Az egészséges életmód szerepének felértékelődésével egyre több kutatás irányul azoknak a szolgáltatásoknak a vizsgálatára, melyek az egészség megőrzését vagy az életminőség megtartását, a prevenciót szolgálják. Így az életmód elemek vizsgálata kapcsán a sportolási szokások, a sportfogyasztási trendek és a sportszolgáltatások vizsgálata napjainkban a hazai és nemzetközi kutatók figyelmét is felkeltette (Vorobiova, 2019; Veiga et al. 2017; Müller et al. 2013; Bartha, 2019).

A sportfogyasztás területét vizsgáló nemzetközi trendek tanúsága szerint a fitnesz mozgásformák, a fittség javítását célzó edzésmódszerek egyre népszerúbbek (Müller et al. 2019 b). A fitnesztermek által kínált szolgáltatások népszerűsége Európában fokozódik, melyet hazánkban is tapasztalunk (Lenténé et al. 2020; Pucsok et al. 2020).

\section{Szakirodalmi áttekintés}

A sportolás egészségre gyakorolt pozitív hatását már számos hazai és nemzetközi kutatás megerősítette (Brown et al., 2012; Hillsdon et al. 2005; Müller - Bácsné, 2018; Apo, 2012). A szabadidősportnak és a fizikai aktivitásnak a jelenléte az emberek életmódjában nem csak hasznos rekreációs tevékenységet jelent, de az egészséget támogató és védő faktora miatt egészség-gazdasági vonatkozása sem elhanyagolható (Pratt et al. 2014; Gabnai et al. 2019).

Napjainkban a fitnesz egyre nagyobb népszerüsége vitathatatlan a sportszolgáltatások piacán. Amellett, hogy képes az új típusú fogyasztói igényeket kielégíteni, nem elhanyagolható előnye, hogy a szolgáltatóknak bevételt generálva hozzájárul a helyi sportpiac dinamizálásához (Fenyves et al. 2019; Kerezsi-Erdey, 2019).

A fitneszszolgáltatók hazánkban is egy növekvő igényt elégítenek ki. A bővülő sport és wellness szolgáltatásokat a városokban lakók képesek és hajlandóak is megfizetni. Egyre több olyan kutatás látott napvilágot, mely a fitneszfogyasztók létesítményválasztás vagy mozgásprogram választás motivációjával foglalkozik (Bartha et al. 2018, Pucsok et al. 2020), emellett a trendek, mozgásformák és edzésmódszerek feltérképezése is olyan fontos kutatási területek, amelyek segíthetik a szolgáltatókat a fogyasztói igényekhez igazított kínálat fejlesztésében, mely a versenyképességük egyik eleme (Vorobiova, 2019; Müller et al. 2013; Jang - Choi, 2018; Chow et al. 2016).

\section{Anyag és módszer}

Kutatásunk sortán az Észak-alföldi régióban mûködő fitnesztermek $(n=24)$ kínálati elemeit vizsgáltuk meg. A mintavétel során arra törekedtünk, hogy a régió mind három megyéjébôl (Jász-Nagykun-Szolnok, Hajdú-Bihar és Szabolcs Szatmár-Bereg) legyen válaszadó szolgáltató. A vizsgálat során kíváncsiak voltunk arra, hogy hogyan alakulnak az általunk vizsgált régiós fitneszszolgáltatók kínálati elemei és ezek a kínálati elemek összhangban vannak-e a keresleti trendekkel. A kutatás során kérdőíves vizsgálatot végeztünk. Az általunk összeállított kérdőív zárt és nyitott jellegú kérdéseket egyaránt tartalmazott, amely a létesítmény és a termek felszereltsége mellett a szolgáltató által kínált óratípusokat is fel kívánta térképezni. Az adatokat Excel szoftver segítségével dolgoztuk fel. Az eredmények értékelésekor számítottunk átlagot és szórást, melyeket grafikusan is ábrázoltunk. 


\section{Eredmények}

Kutatásunk során először megvizsgáltuk az általunk felmért fitnesz-szolgáltatók helyiségeinek számát (átlag=6,12, sd=1,7), melyet az elsô táblázatban tüntettünk fel. Az eredmények alapján megállapítható, hogy a szolgáltatók elegendő számú helyiséggel rendelkeznek ahhoz, hogy a különböző csoportos órákat vagy termi szolgáltatásokat biztosítani tudják a vendégeknek. Az infrastruktúra meglétének főbb jellemzőit a csoportos foglalkozásokra is alkalmas termek átlagos száma 1,8 ( $\mathrm{sd}=1,94)$, a cardio és izotóniás gépekkel felszerelt termek átlagos száma (átlag= 2,17, sd=1,94), valamint a szabadsúlyos edzésekhez használt termek átlagos száma (átlag=1, sd=0) mutatja. Az adatokból látható, hogy a gépekkel felszerelt, valamint a csoportos órákat kielégítő termeket helyezik a szolgáltatók a fókuszba, hiszen ezekből van a legtöbb.

\section{1. táblázat. Az Észak-alföldi régióban müködő fitneszszolgáltatók helyiségeinek alakulása}

\begin{tabular}{|l|c|c|}
\hline & Átlag & Szórás \\
\hline Helyiségek száma & 6,12 & 1,7 \\
\hline Csoportos foglalkozások tartására alkalmas termek száma & 1,8 & 1,94 \\
\hline Cardio és izotóniás gépekkel felszerelt termek száma & 2,17 & 1,94 \\
\hline Szabadsúlyos edzésekhez használt termek száma & 1 & 0 \\
\hline
\end{tabular}

Kíváncsiak voltunk arra is, hogy milyen egyedi kínálat jelenik meg a fitnesz szolgáltatókra leginkább jellemző gépekkel felszerelt és a csoportos órákat kielégítő termeken kívül. Az 1. ábrán láthatjuk, hogy a spinning terem az általunk vizsgált 24 szolgáltatóból kilencnél megtalálható, emellett öt szolgáltatónál találtunk küzdősport termet és négy esetben fallabda pályát. A TRX terem két, a falmászásra alkalmas terem egy szolgáltatónál jelent csak meg. Ennek alapján azt mondhatjuk, hogy a spinning nagyon jól kiegészíti a fitnesztermek egészségmegőrzéssel, kondicionálással és állóképesség-fejlesztéssel kapcsolatos szolgáltatásait.

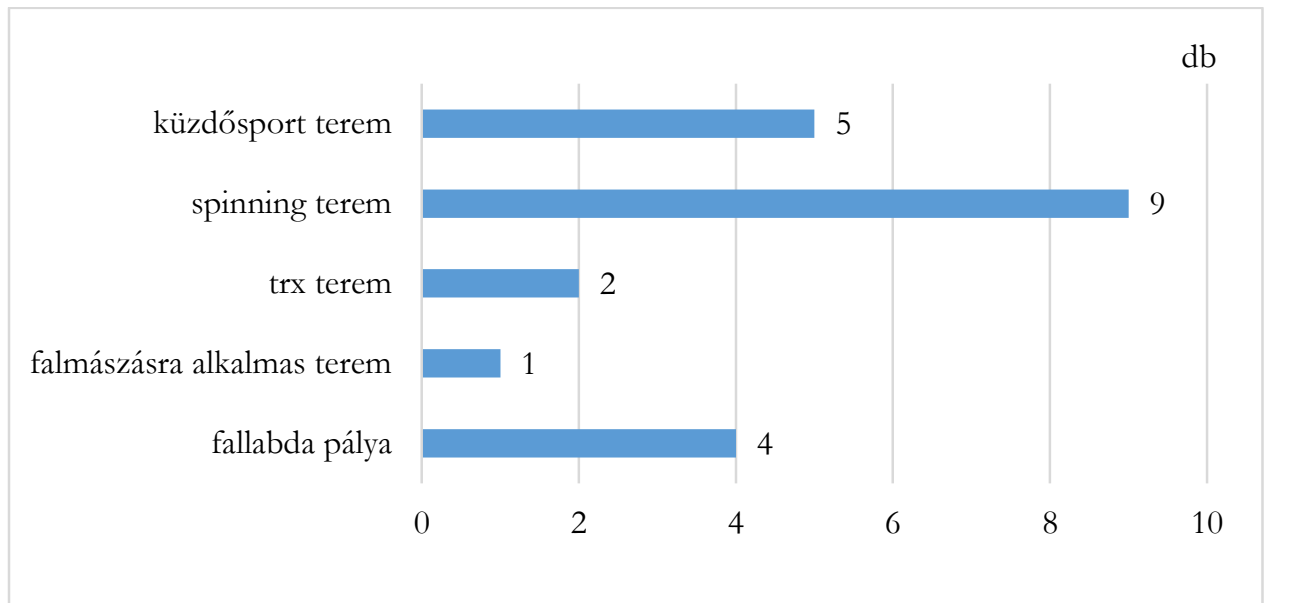

\section{1. ábra. Az Észak alföldi régióban vizsgált fitneszszolgáltatók által üzemeltetett létesítmény egyéb helyiségeinek száma}


Számos kutatási eredmény igazolja azt, hogy a jövőben a szolgáltatók versenyképességét a kiegészítő szolgáltatások megléte és annak minősége nagyban befolyásolja. A 2. ábrán az üzemeltetéssel kapcsolatos sajátosságokat ábrázoltuk. A kiegészítő szolgáltatások közül ilyen például a saját parkoló megléte, mely az általunk vizsgált szolgáltatók (n=24) közül 21-nél megtalálható, ebből 19-nél ez ingyenesen biztosított a vendégek számára (2. ábra). Hasonló szolgáltatás a saját beléptető rendszer, mellyel 17 szolgáltató rendelkezik, ami nemcsak a vendégek fogadását teszi komfortosabbá, hanem a digitalizált rendszer alkalmazásával az adminisztrációs terheket is csökkenti. A klimatizált helyiségek szintén a vendégek komfortérzetét növelik a nyári meleg napokon, valamint az elégedettség szempontjából nélkülözhetetlen a magas hőtermeléssel járó erőteljes intenzitású, vagy hoszszú időn keresztül végzett edzésmunkák során is. A szolgáltatók közül 8 azt nyilatkozta, hogy valamennyi helyiségükben van klíma berendezés, 11 esetben pedig részben klimatizáltak a helyiségek.

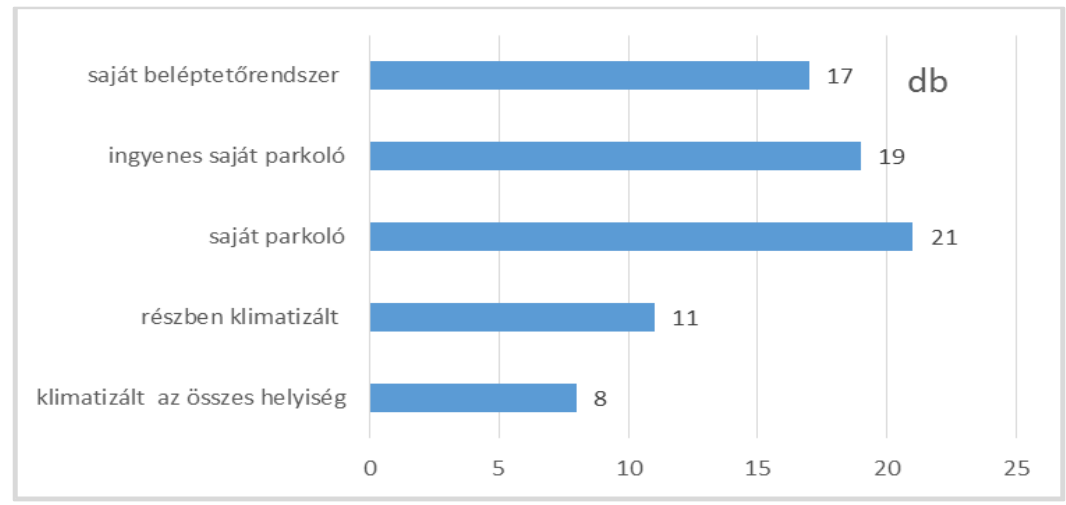

2. ábra. A vizsgált fitneszszolgáltatók üzemeltetésének sajátosságai.

A 3. ábrán láthatóak a wellness elemeket jelentő kiegészítő szolgáltatások. Megfigyelhető, hogy a kereslet igényeire alapozva a szolgáltatók közül a legtöbben a szoláriumot (19db), majd a szaunát (18db) és a masszázst (14db) biztosítják a vendégek számára. Ennek oka, hogy a szauna és masszázs igen alkalmas az edzés utáni fáradtság tüneteinek kezelésére, serkenti a regenerációt és a pihenést is. Ezen szolgáltatások a wellnessben stresszoldó és közérzetjavító hatásuk miatt igen népszerű kínálati elemeknek bizonyultak, mint ahogy a fitnesz szolgáltatóknál is.

A rendszeres edzésre járást megkönnyíti a kisgyermekes anyukák számára a gyermekmegőrző, amely öt szolgáltatónál jelenik meg. Továbbá a hölgyek részérôl igényként jelenik meg az is, hogy az edzést követően igénybe tudjanak venni szépészeti szolgáltatásokat. Az általunk felmért szolgáltatók közül beauty részleget négy szolgáltató tud ajánlani a vendégeknek (3. ábra).

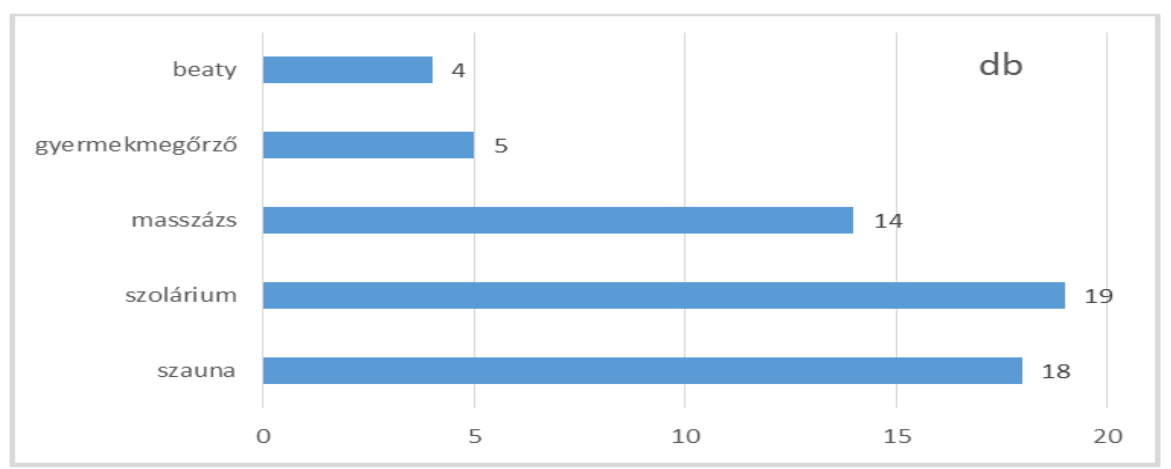

3. ábra. A fitneszszolgáltatók által kínált kiegészítő szolgáltatások 
Rákérdeztünk a fitnesztermek felszereltségére is, azaz, hogy milyen gépeket és azokból mennyit biztosítanak a vendégeknek. Fontos, hogy a gépek sokszínú kínálata lehetőséget biztosítson a különböző mozgásprogramok és edzésmódszerek elvégzésére, azonban ennek mennyisége is fontos a kapacitás szempontjából, illetve ezeknek a minőségére is nagy hangsúlyt kell fektetni (Torkos, 2009). Amennyiben egy szolgáltató széles vendégkört tudhat magáénak elengedhetetlen, hogy kellő számú gép és berendezés álljon rendelkezésre annak érdekében, hogy a vendégek elkerülhessék a hosszú várakozási időt, mely elégedetlenséget eredményezhetne. A 2. táblázatban tüntettük fel a különböző gépek átlag számát és szórásértékeit. Megfigyelhetjük, hogy a cardio gépekből igen széles kínálata van a szolgáltatóknak, hiszen átlagosan 21 gép áll a vendégek rendelkezésére, amely elegendő kapacitást biztosít. A termekben fontosak ezek a gépek, hiszen egyaránt biztosíthatják a bemelegítést és az alakformálást, valamint a cardio-tréninget is. A cardio gépek közül a futópadból van a termeknek a legnagyobb kínálata, majd az elliptikus trénerből és a kerékpárból. Igen magas az izotóniás gépek átlagos száma is (46 db) mely azt mutatja, hogy az egyes izomcsoportok izolált erejének fejlesztése is dominánsan megjelenik a fitnesz-fogyasztók elvárásaiban.

2. táblázat. A vizsgált régiós fitnesztermek felszereltségének alakulása.

\begin{tabular}{|l|c|c|}
\hline & Átlag & Szórás \\
\hline Cardio gép összes & 21 & 12,35 \\
\hline Futópad & 5,6 & 2,43 \\
\hline Ellipszis tréner & 3,4 & 2,14 \\
\hline Kerékpár & 1,6 & 0,93 \\
\hline Támlás kerékpár & 2,2 & 1,24 \\
\hline Lépcsőző-gép & 1,46 & 0,78 \\
\hline Taposó-gép & 2,1 & 1,1 \\
\hline Evező pad & 2,13 & 1,91 \\
\hline Izotóniás gép & 46 & 35,2 \\
\hline
\end{tabular}

A csoportos foglalkozásokat is vizsgáltuk a szolgáltatók kínálatában. A szolgáltatók közül a legtöbben a köredzést, a cardio-tréninget és az aerobic jellegú mozgásformákat biztosítják a vendégek számára, ezek a legnépszerúbb kínálati elemek. A trendeknek megfelelően a Zumba, a spinning valamint a gerinctréning is megjelenik a kínálatban.

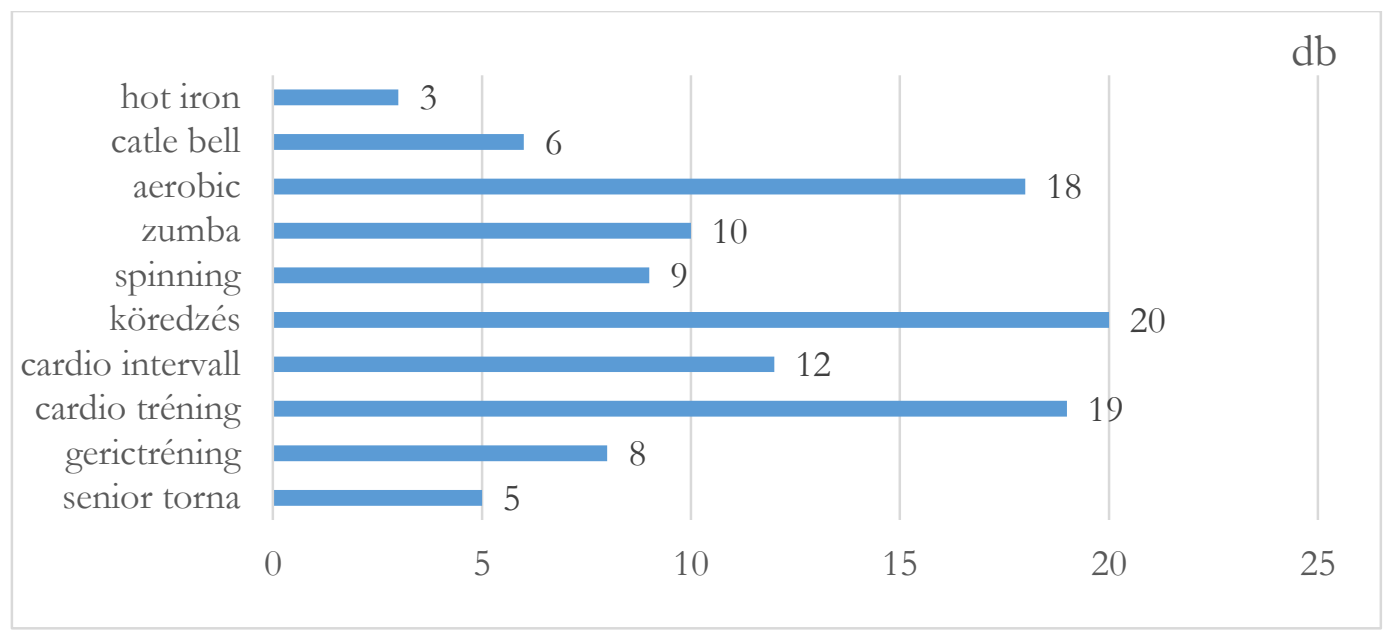

\section{4. ábra. A fitnesz szolgáltatók által kínált óratípusok alakulása}




\section{Következtetések, javaslatok}

Jelen kutatásban az Észak-alföldi régióban található fitneszszolgáltatók (n=24) kínálati elemeit elemeztük az alap és kiegészítő szolgáltatások, valamint az üzemeltetési sajátosságaik tükrében. Azt is vizsgáltuk, hogy ezek a kínálati elemek összhangban vannak-e a hazai és nemzetközi keresleti trendekkel (Thompson, 2020; Müller, 2017). Az Észak-alföldi régió országunk keleti területén helyezkedik el, ahol az ország második legnagyobb városa - Debrecen - található, mely erôs gazdasági potenciállal bír. A régióban megfigyelhető a turisztikai, rekreációs és sportszolgáltatások erős dominanciája a kínálatban, melyekkel igen sok hazai kutatás foglalkozott (Könyves-Müller, 2006; Müller - Könyves, 2006; Tóth - Müller, 2019; Kerényi et al. 2010; Müller - Kórik, 2009). A sport piacán igen szép számban vannak jelen a múködő fitneszszolgáltatók és megfigyelhető, hogy ezek igen nagy gépparkkal rendelkeznek, melyek a cardio edzést és erőfejlesztést teszik lehetővé.

A kutatás eredményei azt bizonyították, hogy a szolgáltatók számára fontos a trendek követése és ennek mentén a szolgáltatások fejlesztése, melyet az infrastruktúrába, a szolgáltatások és kiegészítő szolgáltatások meglétében érvényesítenek, mely eredményeink egybevágnak más hazai és nemzetközi kutatások eredményeivel (Jang - Choi, 2018, Chow et al. 2016; Müller - Kerényi, 2009; Müller et. al. 2013; Müller et.al. 2019; Bartha, 2019; Bartha et al. 2018). A fogyasztók igénylik nem csak a szolgáltatások mennyiségi kínálatát, de a minőség is egyre erőteljesebben jelenik meg, mint fogyasztói igény a sporttermékek (Mórik et al., 2019a; B, Dhurup et al., 2006; Gottfried, 2019), Akár A Sport- És Wellness Szolgáltatások (Bíró et al., 2019) piacán. A kutatás megerősítette, hogy a vizsgált régiós fitneszszolgáltatók kínálatában elég nagyszámú kondicionálótermi gépeket kínálnak (cardio és izomerősítő gép), valamint a trendekhez és fogyasztói elvárásokhoz igazodó csoportos óra megtartására alkalmas légkondicionált termek állnak a vendégek rendelkezésére a kiegészítő szolgáltatásokkal társítva.

A publikáció elkészitését ą EFOP-3.6.2-16-2017-00003 sqámú projekt támogatta. A projekt az. Európai Unió támogatásával, az. Európai Szociális Alap társfinanszírozásával valósult meg.

\section{Hivatkozott források}

[1.] Apor P. (2012): Testedzéssel a megbetegedések ellen. Magyar Tudomány, 173, 1470-1477.

[2.] Bartha É. J. - Müller A. - Bácsné Bába É. (2018): A fitnesz fogyasztók sportlétesítmény választását befolyásoló legfőbb szempontok alakulása életkor szerint. Selye E-Studies, 9(1), 4-12. forrás: http://old.e-studies.ujs.sk/hu/cimlap/cat view/1-e-studies-hu.html?limit=5\&limit$\underline{\text { start }=0 \& \text { order }=\text { date } \& \text { dir }=\text { DESC }}$

[3.] Bartha É. (2019): Fitnesz vendégek sportfogyasztási szokásai. Közép-Európai Köqlemények, 12 (2), 149-161.

[4.] Bíró M. - Molnár A. - Hidvégi P. - Mikhárdi S. - Pucsok, J. M. - Lenténé, P. A. (2019): The role of massage in tourism, and the hotels offerings. In: Hungary.In: Jaromír, Šimonek- Beáta, Dobay (szerk.) Sport science in motion: Proceedings from the scientific conference Zbornik vedeckých a odborných prác ₹vedeckej konferencie = Válogatott tanulmánykötet $:$ Válogatott tanulmányok a tudományos konferenciáról. Komárom: Univerzita J. Selyeho V Komárne, pp. 27-36.

[5.] Chow L. S. - Odegaard A. O. - Bosch T. A. - Bantle A. E. - Wang Q. - Hughes J. - Ryder J. (2016): Twenty year fitness trends in young adults and incidence of prediabetes and diabetes: the CARDIA study. Diabetologia, 59(8), 1659-1665. DOI: 10.1007/s00125-016-3969-5 
[6.] Dhurup M. - Singh P. C. - Surujlal J. (2006): Customer service quality at commercial health and fitness centres. South African Journal for Research in Sport, Physical Education and Recreation. 28(2), 39-54. DOI: $10.4314 /$ sairs.v28i2.25942

[7.] Fenyves V. - Bács Z. - Bácsné Bába É. - Kerezsi D. (2019): Analysis of major capital structure indexes of organizations dealing with sports activities and their relation with the notes to the financial statement. Annals of the University of Oradea, Economic Science Series, 28 (2), 129-136.

[8.] Gabnai Z. - Müller A. - Bács Z. - Bácsné, Bába É. (2019): A fizikai inaktivitás nemzetgazdasági terhei. Egészségfejlesztés, 60(1), 20-30. DOI: 10.24365/ef.v60i1.308

[9.] Gottfried P. (2019): A részvételi sportszolgáltatás vizsgálata a G4 2.0 edzőterem példáján keresztül. In: Balogh L. (szerk.): Sokoldalú sporttudomány. Debrecen: Debreceni Egyetem Sporttudományi Koordinációs Intézet, pp. 29-40.

[10.] Jang W. Y. - Choi K. (2018): Factors influencing choice when enrolling at a fitness center. Social Behavior and Personality: an International Journal, 46(6), 1043-1056. DOI: 10.2224/sbp.7104

[11.] Kerényi E. - Müller A. - Könyves E. - Lázárné Fodor I. - Mosonyi A. (2010): Turisztikai márka és termékfejlesztés lehetőségei az egészségturizmusban az Észak-magyarországi és az Észak-alföldi régiókban. Acta Academiae Paedagogicae Agriensis Nova Series: Sectio Sport, 37, 6773.

[12.] Kerezsi D. - Erdey L. (2019): A magyar sportvállalkozások kiegészítő mellékleteinek vizsgálata a mérleghez kapcsolódóan. Acta Carolus Robertus, 9(2), 73-88. DOI: $\underline{10.33032 / a c r .2019 .9 .2 .73}$

[13.] Könyves E. - Müller A. (2006): Az Észak-alföldi régió turizmusfejlesztési stratégiája 20072013. In: Aubert, A (szerk.): Fejlesztés és képzés a turizmusban: II. Országos Turisztikai Konferencia tudományos közlleményei. Pécs: Pécsi Tudományegyetem Természettudományi Kar Földrajzi Intézet, p. 2007.

[14.] Lenténé Puskás A. - Pucsok J.M. - Hidvégi P. - Bíró M. (2020): Debreceni fitneszszolgáltatók kínálatának elemzése. Acta Carolus Robertus 10(1), 81-93. DOI: 10.33032/acr.2020.10.1.81

[15.] Hillsdon M.M. -Brunner E.J. - Guralnik J.M. - Marmot M. G. (2005): Prospective study of physical activity and physical function in early old age. Am J Prev Med, 28(3), 245-250. DOI: 10.1016/j.amepre.2004.12.008

[16.] Mórik K. V. - Bácsné, Bába É. - Müller A. - Ráthonyi G.G. - Molnár A. (2019): The appearance of product innovation in the life of a Hungarian SMEs in the global market of sporting goods - implications from a research. Geosport For Society, 10(1), 25-38. DOI: 10.30892/gss.1003-045

[17.] Müller A. - Bíró M. - Hidvégi P. - Váczi P. - Dávid L.D. - Szántó Á. (2017): A 2016-os fitnesztrendek helye és szerepe a rekreációban. Acta Academiae Paedagogicae Agriensis Nova Series: Sectio Sport, 44, 91-102.

[18.] Müller A. - Bíró M. - Hidvégi P. - Váczi P. - Plachy J. - Juhász I. - Hajdú P. - Seres J. (2013): Fitnesz trendek a rekreációban. Acta Academiae Agriensis, 40, 25-35.

[19.] Müller A. - Kerényi E. (2009): Trendek és fogyasztói magatartás az egészségügyben. In: Kerényi, Erika (szerk.): Egészségügyi marketing és telekommunikáció. Mátraháza: Mátrai Gyógyintézet, pp. 11-19.

[20.] Müller A. - Bácsné, Bába É. - Gabnai Z. - Pfau C. - Pető K. (2019a): A fitnesztrendek és új típusú mozgásformák társadalmi és gazdasági aspektusai. Acta Carolus Robertus, 9(2), 109-122. DOI: $10.33032 /$ acr.2019.9.2.109

[21.] Müller A. - Bácsné, Bába É. (2018): Az egészséges életmód és a sport kapcsolata. Létavértes: Létavértes SC '97 Egyesület.

[22.] Müller A. - Kórik V. (2009): Az észak-alföldi fürdôk szerepe a turizmusban és a rekreációban. Economica, 2, 58-72. 
[23.] Müller A. - Könyves E. (2006): Az egészségturizmus lehetőségei az Észak-alföldi régióban. Acta Academiae Paedagogicae Agriensis Nova Series: Sectio Sport, 33, 132-143.

[24.] Müller A. - Lengyel A. - Koroknay Zs. - Molnár A. (2019b): Népszerű fitnesz mozgásformák. In: Bácsné, Bába Éva; Müller, Anetta (szerk.) "Mozgással az egészségért" A fizileai aktivitás jelentösége a jövö munkavállalóinak egészségmegörzésében: Nemzettoözi Konferencia és Workshop: Válogatott tanulmánykötet = "Movement for health" The importance of physical activity in health protection of future workers: International Conference and Workshop: Proceedings from the International Conference and Workshop. Debrecen: Debreceni Egyetem, pp. 106-112.

[25.] Pratt M. - Norris J. - Lobelo F. - Roux L. - Wang, G (2014): The cost of physical inactivity: moving into the 21 st century. British Journal of Sports Medicine, 48, 171-173. DOI: $10.1136 /$ bjsports-2012-091810

[26.] Pucsok J. - Bíró M. - Czegledi H. O. - Lenténé Puskás A. - Borók O. - Hidvégi P. (2020): A nemzetközi fitness trendek megjelenése az Észak- alföldi régióban - elemzés I. In: Balogh, László (szerk.): Trendek a versenysport és a szabadidösport területéröl. Debrecen: Debreceni Egyetem Sporttudományi Koordinációs Intézet, pp. 184-192.

[27.] Thompson W. R. (2020): Worldwide survey of fitness trends for 2020. American College of Sports and Medicine. Letöltés dátuma: 2020. 12.10. forrás: https://journals.lww.com/acsmhealthfitness/Fulltext/2019/11000/WORLDWIDE SURVEY OF FITNESS TRENDS FOR 2020.6.aspx

[28.] Torkos Z. (2009): A világ legjobb fitnesz gépeinek tervezése, az egészség megóvására összpontosítva, a Life Fitness budapesti tervező központjában. In: XIV. Fiatal Müszakiak Tudományos Ülésszaka. Kolozsvár: Erdélyi Múzeum-Egyesület, pp. 221-224.

[29.] Tóth A. - Müller A. (2019): Jász-Nagykun-Szolnok megyei fürdők szabadidős és sportkínálatának vizsgálata. Acta Carolus Robertus, 9(2), 175-189. DOI: 10.33032/acr.2019.9.2.175

[30.] Veiga Ó. L. - Valcarce Torrente M. - King Clavero A. (2017): National survey of fitness trends in Spain for 2017. Apunts. Educación Física y Deportes, 128, 108-125.

[31.] Vorobiova, A. (2019). World and national fitness trends 2019. Sport science and buman bealth, 1(1), 62-69. DOI: 10.28925/2664-2069.2019.1.2

[32.] Brown W.J. -McLaughlin D. -Leung J. - McCaul K. A. - Flicker L. - Almeida O. P. - Hankey G. J. - Lopez D. - Dobson A. (2012): Physical activity and all-cause mortality in older women and men. British Journal of Sports Medicine, 46 (9), 664-668. DOI: 10.1136/bjsports-2011-090529 


\section{Szerzők}

Lenténé Dr. Puskás Andrea

adjunktus

Debreceni Egyetem

Sporttudományi Koordinációs Intézet

lpandrea@sport.unideb.hu

Hidvégi Péter

docens

Debreceni Egyetem

Sporttudományi Koordinációs Intézet

hidvegi.peter@sport.unideb.hu

Pucsok József Márton

docens

Debreceni Egyetem

Sporttudományi Koordinációs Intézet

pucsok.jozsef@sport.unideb.hu

Czeglédi Hanna Orsolya

egyetemi hallgató

Debreceni Egyetem

Vidékfejlesztés, Turizmus- és Sportmenedzsment Intézet

czegledi.hanna.orsolya@gmail.com

Bíró Melinda

docens

Debreceni Egyetem

Sporttudományi Koordinációs Intézet

biro.melinda@sport.unideb.hu 